18th Annual International Conference of the IEEE Engineering in Medicine and Biology Society, Amsterdam 1996 1.6.1: Microfabrication I

\title{
A Microsieve for Leukocyte Depletion of Erythrocyte Concentrates.
}

\author{
Cees van Rijn, Wietze Nijdam and Miko Elwenspoek \\ MESA Research Institute, Faculty of Electrical Engineering, \\ University of Twente, P.O. Box 217, 7500 AE Enschede, The Netherlands \\ c.j.m.vanrijn@el.utwente.nl
}

\begin{abstract}
A new ultra thin filtration membrane has been used for leukocyte removal from erythocyte concentrates. This filtration membrane, an Aquamarijn Microsieve ${ }^{\otimes}$, has a high pore density and a narrow pore size distribution and shows good separation behaviour. The low surface roughness of the microsieve will contribute to the biocompatibility and will reduce cell rupture, in particularly hemolysis, during filtration.

In this paper a brief overview of the effects that occur during filtration will be given. Also the results of the experiments of leukocyte removal from erythrocyte concentrates will be discussed here.
\end{abstract}

\section{INTRODUCTION}

In systems where cells should be separated from each other (cell-cell separation) a very thin perforated plate (microsieve) supported by a grid lias the advantage that cells will remain only a very short time in the pores leading to a low activation, sticking or rupture of cells [1].

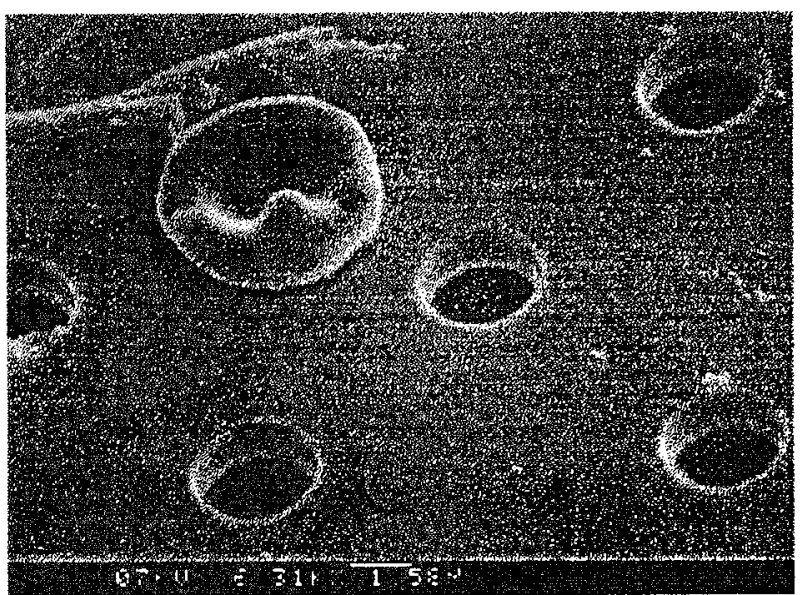

Figure 1, an erythrocyte on top of the filtration membrane of a microsieve. Note the uniformity of the pores.

With silicon micro machining it is possible to make microsieves [4] with a porcsize between e.g. $0.5 \mu \mathrm{m}$ and $10 \mu \mathrm{m}$ with high reproducability. The main 'tools' for production are: thin film deposition. pattern definition (for an etch mask) and wet or dry etching.
Siliconnitride $\left(\mathrm{Si}_{3} \mathrm{~N}_{4}\right)$ is used as a material for the membrane (thickness between 0.5 and $2 \mu \mathrm{m}$ ) and the membrane is supported by a $<100>$-silicon wafer in which large openings are being etched. The width of this support is $100 \mu \mathrm{m}$ and the openings are $1000 * 1000 \mu \mathrm{m}$ (see figure 2).

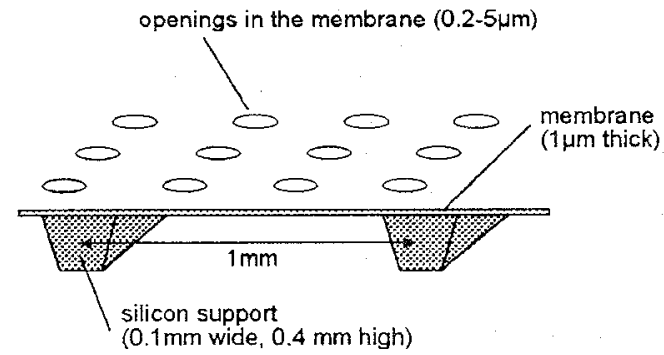

Figure 2, schematic sideview of the microsieve and the support.

\section{LEUKOCYTE DEPLETION OF ERYTHROCYTE CONCENTRATES}

Nowadays advanced centrifugal techniques are used to obtain erythrocyte concentrates from whole blood. However the concentrates are still contaminated with relatively large amounts of leukocytes.

These blood cell concentrates are normally used for blood transfusion. At present the remaining leukocytes in the concentrates are further depleted mainly by using non-woven filters. The mechanism of depletion [5] is adsorption to the fibers (depth filtration) through enhancing the activation of the leukocytes. In advanced filters additional filtration is obtained by a kind of sieving using compact sheets of very thin fibers with a diameter of only a few microns. The additional filtration with non-woven filtcrs however is not $100 \%$ and gives also rise to a relatively great loss of bloodcells $(10 \%$ to $40 \%)$ due to the large dead volume $[2,3]$ of the filter pack.

A depletion mechanisin solcly based on sieving with use of thin perforated membrane plates would be a good alternative. Most existing membranes however are not suitable for cell-cell separation because of the low flow rate. the adsorption of cells to the membrane surface and the high surface roughness comparable with the size of the cells. 
18th Annual International Conference of the IEEE Engineering in Medicine and Biology Society, Amsterdam 1996 1.6.1: Microfabrication I

\section{MATERIALS AND METHODS}

Preparation of the filtration membranes. Microsieves (Aquamarijn Microsieve $\left.{ }^{(}\right) \operatorname{SiN} 1.4$ and SiN1.6) with a siliconnitride membrane layer (thickness of $1 \mu \mathrm{m}$ and pore sizes of 4 and $6 \mu \mathrm{m}$ ) have been uscd for performing leukocyle depletion experiments. Before trial the membranes have been cleaned in fuming and subsequently boiling nitric acid. The surface area of all microsieves was $12 \mathrm{~cm}^{2}$ with a pore density of $1-10^{6}$ pores per $\mathrm{cm}^{2}$.

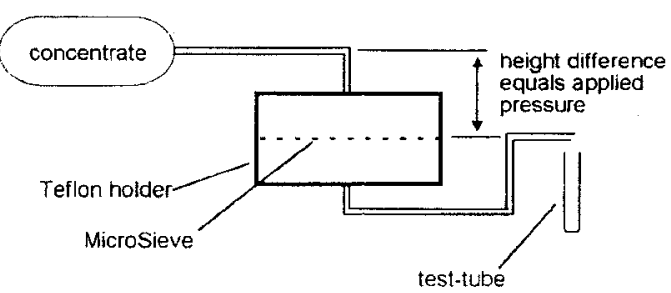

Figure 3, overview of the test set-up.

Preparation of the concentrates. Units (200ml) of whole blood have been centrifuged and processed within 3 hours after donation. One buffy coat depleted erythrocyte unit was subsequently filtcred using an Asahi R2000 Sepacell filter in order to decrease the leukocyte concentration.



Figure 4, different blood cells on the filtrationsurface (erythrocytes and lymfocytes).

Filtration studies. For each of the membrane evaluations, the microsieve was placed into a Teflon based holder and connected in series between the concentrates and test-tubes (see figure 3). The applied pressure was adjusted by changing the height difference between the concentrate and the filter holder. Before and after the experiments, samples have been taken for component counting (Coulter cell-counter). Very low leukocyte con- centrations were determined using a microscope and a Nageottc counting chamber.

\section{RESULTS}

When filtrating the cell concentrates the pressure across the membrane slightly rises in the beginning with a few $\mathrm{cm} \mathrm{H}_{2} \mathrm{O}$. Precautions were taken to reduce this effect at very low transmembrane pressures during experiments. The addition of a small amount of plasma may be used for wetting the membrane surface. For pore sizes larger than $2 \mu \mathrm{m}$ wetting is not necessary. The results of the initial experiments are shown in table 1 .

\begin{tabular}{|r|r|r|r|r|r|r|r|r|}
\hline $\begin{array}{r}\text { Pore } \\
\text { size }\end{array}$ & Vol. & $\begin{array}{c}\text { Vol. } \\
\text { loss } \\
\text { after } \\
\text { exp. }\end{array}$ & $\begin{array}{c}\text { tocryt } \\
\text { tom] }\end{array}$ & $\begin{array}{c}\text { Enthro- } \\
\text { cytes }\end{array}$ & $\begin{array}{c}\text { Incr. of } \\
\text { Hemo- } \\
\text { lysis }\end{array}$ & $\begin{array}{c}\text { WBC } \\
\text { before } \\
\text { exp. }\end{array}$ & $\begin{array}{c}\text { WBC } \\
\text { deple- } \\
\text { tion } \\
\text { after } \\
\text { exp. }\end{array}$ & $\begin{array}{c}\text { Membrane } \\
\text { Pressure } \\
{\left[\mathrm{mm} \mathrm{H}_{2} \mathrm{O}\right]}\end{array}$ \\
\hline 4 & 200 & $1.5 \%$ & $55 \%$ & 6.5 & $0.01 \%$ & 11 & $85 \%$ & 50 \\
\hline 6 & 200 & $2 \%$ & $64 \%$ & 7.5 & $0.15 \%$ & 6000 & $95 \%$ & 75 \\
\hline
\end{tabular}

Table 1, Leukocvte depletion of erythrocyte concentrates using a microsieve with various pore sizes.

\section{CONCLUSIONS}

In this study a new type of filtration membrane with unique properties (high flow rate, uniform poresize distribution) has been used for leukocyte depletion in eythrocyte concentrates. The microsieve has a high biocompatibility. In the initial experiments leukocyte depletion has becn found. New experiments performed at lower pore sizes, in a cross-flow filtration set-up and with pulsatile back-flush should give a lcukocytc depletion over $95 \%$. In a next study we will report on this and present also some results for separating bloodplasma from whole blood using a microsieve with a pore size below $1 \mu \mathrm{m}$.

\section{REFERENCES}

[1]. Arai, K., M. lino, H. Shio and N. Uyesaka, 1990. Further investigation of red cell deformability with nickel mesh, Biorheology 27:47-65.

[2]. Dreisbach, A.W., M. Madan and V. Batuman, 1991, Cell volume changes in filtration studies of red cell deformability, Clinical Hemorheology 11:295-302

[3]. Hitzler, W., 1993, Der gegenwärtige Stand der Blutfitration Grundlagen und klinische Bedeutung van Leukozytendepletions- und Mikroaggregatfiltern bei der Bluttransfusion, Anästhesiol. Intensivmed. Notfallned. Sclimerzther. 28:341-351.

[4]. Rijn, C.I.M. van and M.C. Elwenspoek, 1995, Micro filtration Membrane Sieve with Silicon Micro Machining for Industrial and Biomedical Applications, Proceedings IEEE Micro Mechanical Systems, Amsterdam, The Netherlands, pp. 83-87.

[5]. Steneker, I., 1994, Leukocyte-poor blood products: filtration mechanisms, Vox sanguinis 67:159-160. 